\begin{tabular}{l|lr}
$\begin{array}{l}\text { Università } \\
\text { della } \\
\text { Svizzera } \\
\text { italiana }\end{array}$ & $\begin{array}{l}\text { Faculty } \\
\text { of Economics }\end{array}$ & IdEP Economic Papers \\
& & $2016 / 06$
\end{tabular}

M. Vatiero

Learning from the Swiss corporate governance exception 


\title{
Learning from the Swiss corporate governance exception
}

\author{
Massimiliano Vatiero*
}

(pre-print version, forthcoming on Kyklos)

\begin{abstract}
The Swiss economy represents an exception to the legal origin theory (e.g., Roe (2006)). Although Switzerland is a country belonging to the civil law family, many of its public companies have diffused corporate ownership, as do those in common law countries. This paper maintains that the Swiss exception relies on the complementarity between corporate ownership and policies addressing employment protection and innovation. The Swiss case presents two lessons: first, the current corporate governance is the result of a long and composite path in which politics plays a pivotal role; second, the institutional differences and similarities across countries, which one would try to explain along with the legal origin theory, can derive diversely from additional politics-based accounts, such as those referring to policies on employment protection and innovation.
\end{abstract}

Keywords: corporate governance and ownership, innovation, employment protection, institutional complementarity, Swiss economy.

JEL Code: G30, J50, 016, P16.

* Assistant professor of Law and Economics-Brenno Galli Chair of Economic Analysis of Law, Università della Svizzera italiana, Lugano (Switzerland), email: vatierom@usi.ch. The author acknowledges comments from Carl Baudenbacher, Filippo Belloc, Federica De Rossa, Bruno Frey, Giuseppe Niglia, Ugo Pagano, Marcello Puca, Mark Roe, Hans-Bernd Schäfer, Mathias Siems, David Soskice, an anonymous referee, editors of this journal, and participants of EALE 2013 (Warsaw) conference. The author is grateful for financial support provided by the Swiss National Science Foundation and for the visiting fellowship of the Comparative Corporate Governance and Finance Program at Harvard Law School. The usual disclaimers apply. 


\section{The issue}

Recent literature notes that Switzerland represents an exception to the legal origin theory-Mark Roe writes, "Switzerland fits awkwardly with a legal origin perspective" (Roe 2006:508) - for the fact that, though it is a civil law country, its economy is characterized by large firms with diffused corporate ownership which resembles those of common law countries. ${ }^{1}$ Our account of the Swiss exception relies on complementarities between diffuse corporate ownership and politics addressing weak employment protection and supporting the so-called radical innovation. This means that politics did not complete its influence on institutions back when the legal families originated but continues to be a driver for the evolution of the governance of corporations.

In a similar "political economy" perspective, ${ }^{2}$ Mark Roe (2006) argues that the destruction and military occupation during WWII, which ruined European institutions, heightened voters' insecurity. In Austria, France, Germany, and Italy, the financial savings of the middle class were devastated, and, therefore, for decades after 1945, typical voters in such nations have cared little about protecting financial capital because they had little of it, whereas their well-being was tied more to their human capital (Roe 2006:498). Because of the WWII, in Austria, France, Germany, and Italy, the median voter forced politicians to create strong labour protection rather than protect financial capital. Consequently, corporate owners in these countries reacted by concentrating ownership. That is, stronger employees' political rights ("stronger social democracies", in the terminology of Roe (2003)) induced owners of corporations in neighbouring countries of Switzerland to react by creating a higher concentration of corporate ownership in order to safeguard their quasi-rents.

On the contrary, Switzerland, which during WWII "suffered neither a military occupation nor a violent revolution" (Roe 2006:509), continued to have a labour law characterized by relatively weaker protection for workers and corporations with diffused ownership structures. This paper complements Roe's account. Our argumentation adds that the Swiss exception also derives from policies both on innovation and on labour, including years before WWII.

Exploring the complementarity between corporate ownership and labour protection, this paper illustrates the role of the 1937 Swiss "industrial peace agreement" in the evolution

\footnotetext{
${ }^{1}$ Pagano (2012), and Belloc and Pagano $(2009,2013)$ also advance a similar observation.

${ }^{2} \mathrm{Cf}$. Roe and Vatiero (2016) for a survey on this perspective.
} 
of Swiss corporate governance. The Nazi-Fascism arising in the neighbouring states of Switzerland pushed Swiss employer and employee representatives to sign a peace agreement that shaped the Swiss corporate governance equilibrium. On the other hand, using the complementarity between corporate governance and innovation (e.g., Hall and Soskice (2001), Carlin and Mayer (2003)), this paper argues that the Swiss policies on intellectual property rights implemented at the end of the $19^{\text {th }}$ century contribute to explain the Swiss exception.

The main lesson to be learned from the Swiss case is that politics matters in the evolution of corporate governance and that institutional complementarities may constitute a hereditary mechanism that explains institutional diversities (cf. Aoki (2001), Pagano and Vatiero (2015), Vatiero (2016)). Institutional complementary theory suggests that various elements can consistently complement each other to form path-dependent economic outcomes within broader institutional contexts (see also Pagano and Vatiero (2015)). In this paper, I emphasize that politics has a pivotal role in this path-dependence.

For institutional complementarity, multiple equilibria arise, and the convergence towards a certain Pareto-(in)efficient equilibrium will be more complicated in both theory and practice than a simple smooth and expectable change. On the one hand, changes via politics may not produce institutional or economic readjustments because of the costs of switching from one equilibrium to another; in this case, the initial political condition may have persistent 'lock-in' effects. On the other hand, changes may put in action a circular and cumulative causation leading to large variation of institutions and economic equilibria (cf. Pagano and Vatiero (2015)). For instance, because of the complementarities between innovation and corporate governance, as will be introduced in Section 4, the rise of radical innovative sectors (such as information technology and biotechnologies) around the world in the last decades should push countries towards a corresponding corporate equilibrium characterized by flexibility of assets. In fact, economic institutions in Germany have experienced a shift towards a pro-flexibility direction for the past two or three decades, in which industry-wide collective bargaining has declined, and the bargaining system has turned significantly more fragmented and pluralist (cf. Streeck (2011)). This has also led to the weakening of political paradigm on which the German system of industrial relations has based its competitiveness. Similar processes have been observed in other countries, including France and Italy (cf. Amable (2015)) and Japan (Lechevalier (2014)).

For this reason, the historic distinction between the common-law and civil-law systems, as considered by the legal-origin theory, is only a part of the evolution of corporate governance regimes: Politics did not end its influence on institutions when legal origins began, but it continues to be a driving force. Indeed, as one can learn from the Swiss case, corporate ownership structures vary over time (and across nations) for policies addressing labour protection and innovation.

More generally, using the Swiss case, I state that economic analysis should include the investigation of the establishment and evolution of the political arena. As originally noted by Olson (1982), institutional change is often the outcome of strategies aimed at improving the situation of some or all of the components of the dominant political elite. A further consequence is that such institutional changes "are not necessarily or even usually created to be socially efficient, rather they, or at least the formal rules, are created to serve the interests of those with the bargaining power to devise new rules" (North 1990:16). 
The structure of this paper is as follows. In the next section, I illustrate the exception of Switzerland with respect to the legal origin theory. Section 3 focuses on the complementarity between corporate ownership and employment protection. Section 4 discusses the institutional complementarity between corporate governance and innovation. Section 5 summarizes the results of the paper.

\section{Motivation: Counter-examples of the legal origin theory}

In a series of papers, Shleifer and his co-authors (e.g., La Porta et al. (1997), (1998), (1999), (2008)) affirm that the current structure of corporate ownership in big corporations is a consequence of the distinction between civil and common law systems. Such theorythe so-called legal origin theory-accords a primary role to the roots of the legal system (common law vs. civil law) in the development of property rights, markets, and investor protection.

The legal origin theory is consistent with a political economy view because it considers that institutions depend on political determinants, in particular on the dominant ideologies in France and England on the roles in the society of the King/Queen, Parliament, Judges and individuals. Indeed, Mahoney (2001:504) writes, "English common law developed because landed aristocrats and merchants wanted a system of law that would provide strong protections for property and contract rights, and limit the crown's ability to interfere in markets". By contrast, "French civil law developed as it did because the revolutionary generation, and Napoleon after it, wished to use state power to alter property rights and attempted to insure that judges did not interfere" (Mahoney 2001:505). Accordingly, legal families differ in terms of the 'political priority' they gave to private property rights relative to the rights of the state: a civil law system tends to centralize and intensify state power and therefore takes a more wary stance toward the development of free financial systems than a common law system (cf. also Beck and Levine (2005)).

Using data from La Porta et al. (1999) on the corporate ownership structure of large publicly traded firms and La Porta et al. (1998)'s distinction between common and civil law countries, however, one can find some exceptions to the legal origin theory (cf. Table 1). For example, Japan and South Korea, two civil law countries exhibit (in 1995) ratios of widely held firms that are more similar to common law countries than civil law ones; also, Israel, Singapore, and Hong Kong, three common law countries, have ratios that are more similar to civil law countries than common law ones. Beyond such 'Eastern exceptions', Europe also has (at least) one exception: Switzerland, which is a country with a system of civil law that has high ratios of widely held firms that are more similar to common law countries than civil law countries. ${ }^{3}$ This Swiss exception is more remarkable if we compare Switzerland with its neighbouring civil law systems, i.e., Austria, France, Germany, and Italy. ${ }^{4}$

\footnotetext{
${ }^{3}$ On the fact that Switzerland belongs to civil law family, cf. also Le Roy and Schönenberger (2002:64-74).

${ }^{4}$ Unfortunately, there are not data on Luxembourg in La Porta et al. (1999).
} 
[Insert Table 1 here]

Starting from this observation, I propose a novel political economy explanation for this exception. ${ }^{5}$ Using the institutional complementarity theory, I describe why corporate ownership can vary across different national combinations of policies that address labour protection and innovation.

\section{The domain of labour}

Roe (2006) claims that the Swiss exception derives from different policies after WWII on the labour between Switzerland and its neighboring states. He argues that after WWII, in Italy, France, Austria, and Germany, the political pressures for strengthening the political rights of workers implied a reaction of owners in terms of concentration of corporate ownership. ${ }^{6}$ Aoki (2010), Belloc and Pagano (2009, 2013), and Pagano (2012), among others, suggest that there is a complementarity between labour protection and corporate ownership. This means that two equilibria of corporate governance may emerge. As an arms race, one is the "disarmed" corporate governance equilibrium with a low level of employment protection and low capital concentration; the second one is the "armed" corporate governance equilibrium with heightened protection of employees and high concentration of ownership. This implies that the characterization of one domain (either corporate ownership or labour protection) affects, via complementarity, the characterization of the other. I advance the hypothesis that because the level of employment protection was low, Switzerland did not experience a concentration of the ownership, as its neighbouring countries did.

Compared to other European countries, the Swiss labour market has a high degree of flexibility and relatively little employment protection regulation (cf. also Bonoli and Mach 2001, Duell et al. 2010, Baudenbacher 2012). Table 2 (columns 3a-c) shows that Switzerland has an employment protection system in place that is more similar to common

\footnotetext{
${ }^{5}$ Note that small firms are excluded by the sample in Table 1 and by the analysis of this article because the political struggle among different interests, which this work investigates, is more remarkable and relevant in large firms than small ones (see Davies et al. 2009:306). Including small firms the percentage of widely held firms is significantly lower (see Faccio and Lang (2002)). In particular, Hofstetter (2002:8) reports that, including also small firms, two out of three of all Swiss companies have a controlling shareholder. However, Anderson and Hertig (1994) report that Swiss economy is dominated by large listed firms: as of the early 1990 s, the 30 largest Swiss corporations accounted for almost $80 \%$ of the total market capitalisation.

${ }^{6}$ Corporate law may affect corporate ownership, as well. Since its first formulation, a liberal, individualisticcapitalist perspective has characterized Swiss corporate law and, therefore, has contributed to the persistence of diffused corporate ownership. Conversely, Germany, from where Switzerland imported its first formulation of corporate law, after WWII introduced co-determination, as consequence of political pressures of middle class whose income depended on human capital rather than physical assets, along with Roe's $(2003,2006)$ argument. Note that, here, the introduction of co-determination can be seen as one of policies addressing labour protection (e.g., via workers' voice). This means that differences in corporate law between Switzerland and Germany (and other European countries) are consequences of differences in policies concerning workers' protection. For this reason, our attention in this section is dedicated to the domain of labour.
} 
law countries than its neighbouring countries. Column 4 of Table 2, moreover, reports that the disarmed corporate governance equilibrium characterizes not only common-law nations but also (exceptionally) Switzerland. The reported data support the hypothesis that Swiss corporate governance is more similar to that of common law countries than to the corporate governance that characterizes Switzerland's neighbours-Austria, France, Germany, and Italy — which belong to the civil law family.

[Insert the table 2 here]

This paper complements the argument of Roe (2006), based on labour protection policies adopted after WWII, by introducing a further shock that took place before WWII: the 1937 Swiss "industrial peace agreement" (Friedensabkommen or Vereinbarung zur Einhaltung des Arbeitsfriedens in German, Convention de paix du travail in French). This agreement, which first appeared in the metalworking industry and was initially accepted for two years, has been renewed at five-year intervals ever since and has spread to almost all industrial sectors, becoming a cornerstone of Swiss industrial relations. Reflecting the Swiss desire for concordance and dislike of conflict (cf. Steinberg (2011)), the 1937 agreement set up a dispute resolution procedure that included a peace clause.

This peace agreement produced three main results:

1. Because it was not based on legal requirements but on contractual provisions defined by the parties, ${ }^{7}$ the current norms governing labour relations do not form a distinct labour code but are incorporated in the Code of Obligations alongside contracts.

2. Wages are, to a large extent, fixed at the individual firm's level, leaving employers free to negotiate with their own workforce (cf. also Baudenbacher (2012)). Consistently, in 1976, the Swiss people rejected a popular initiative for employee's participation launched by unions in order to introduce German-like co-determination. ${ }^{8}$

3. Finally, because of the peace agreement, Switzerland has the lowest annual strike rates out of all the OECD countries (cf. Duell et al. (2010), Steinberg (2011), Baudenbacher (2012)).

Given the non-conflictual, contract-based relationship between labour and capital in Switzerland, workers did not ask to national politics for particularly higher protections, and, therefore, there was not the necessity of concentrating ownership for owners to defend their corporate quasi-rent. For this reason, the Swiss industrial peace agreement, which had contributed to a low level of employment protections in Switzerland, has a prominent role in the enduring nature of diffused corporate ownership in Swiss firms.

In this respect, it is worthy to underline the influence of politics. The political environment of neighbouring nations, in particular, played an important role. The 1937 peace agreement stems from the fear of employer and employee representatives that the federal government might impose a sort of corporatism similar to what occurred in Nazi-Fascist

\footnotetext{
${ }^{7}$ The signatory organizations undertook to ensure that the agreement was followed by their members, with each party depositing a security of francs 250,000 in the Swiss National Bank and contractual penalties issued in case of infringement.

${ }^{8} \mathrm{I}$ am in debt with Prof. Baudenbacher for reminding me of the 1976 initiative.
} 
nations, like Germany and Italy. Consequently, the threat of government intervention was an essential factor leading to the peace agreement (cf. Lambelet (1993), Broussolle (2009)). The strategy adopted by employer and employee's representatives was aimed at obtaining mutual recognition without falling under state control. In one of the last meetings before the signing of the peace agreement, the president of SMUV (the main metalworkers' union) affirmed: "we must persuade workers that we will still be threatened by fascism for a long time" (quoted in Broussolle 2009:282). Again, SMUV's leading official stated: "if we reach an agreement in these relatively easy times, it should also be workable when times become harder [war is threatening Europe]" (quoted in Broussolle 2009:281). Employers and employee representatives feared that without an agreement, i.e. the 1937 peace agreement, the government, encouraged by the Nazi-Fascism political movements, would impose direct controls and guild unions resembling the fascist model. Thus, for the introduction of the 1937 Swiss peace agreement, the influence of foreign politics had a key role.

\section{Swiss equilibrium of corporate governance and innovation}

A further complementarity based on political choices relates to the interaction between the form of corporate governance and the kind of innovation (Carlin and Mayer (2000), (2003), Mayer (2000), Hall and Soskice (2001), and Pagano (2012)). This literature argues that there is a complementarity between armed corporate governance equilibrium and incremental sectors (which involve specific investments, where the term specificity is intended along with Oliver Williamson's (1985) contribution) and a complementarity between disarmed corporate governance equilibrium and radical innovation (which relates with general-purpose investments) (cf. Hall and Soskice (2001), Pagano (2012), Roe and Vatiero (2016)). In other words, corporate governance structures characterized by high corporate ownership concentration and high labour protection encourage activities with a "modular" step-by-step progression (i.e., incremental innovation) and committed assets (i.e., asset-specificity). Conversely, corporate governance structures characterized by low corporate ownership concentration and low employment protection stimulate all-ornothing or path-breaking innovation (i.e., radical innovation), providing greater flexibility of work and of capital (i.e., general-purpose assets).

In more detail, Hall and Soskice (2001) underline that the armed equilibrium provides "more institutional support for the strategic interactions required to realize the value of cospecific assets, whether in the form of industry-specific training, collaborative research and development, or the like" (Hall and Soskice 2001:17); indeed, firms in the armed equilibrium are characterized by strong trade unions (which very often supervise collaborative training schemes), powerful work councils, high levels of employment protection, and job tenures. These conditions offer the assurance of positions if employees invest in specific skills. Instead, the more fluid markets of the disarmed equilibrium "provide economic actors with greater opportunities to move their research around in search of higher returns, encouraging them to acquire switchable assets, such as general skills or multi-purpose technologies" (Hall and Soskice 2001:17). Representative incremental sectors are transport, mechanical elements, electrical machinery, civil 
engineering, and chemical engineering, while radical sectors consist of information technology, pharmaceutical, biotechnology, chemistry, and medical sectors (cf. Hall and Soskice 2001).

Columns 2 and 3 in Table 3 report that disarmed equilibria relate with radical innovation. The striking finding is that Swiss innovation is more similar to that of the common law countries than to that of its neighbouring civil law countries. I hypothesize that policies addressing radical innovation encouraged the evolution of the Swiss economy towards a disarmed equilibrium.

[Insert table 3 here]

As noted by many authors (e.g., Kronstein and Till (1948), Machlup and Penrose (1950), Schiff (1971), Kaufer (1989), Moy (1993), Baudenbacher (2012)), Switzerland passed through almost the entire $19^{\text {th }}$ century without patent legislation. Before 1888 , the year of the adoption of the first Swiss federal patent law, several attempts to introduce a patent system failed (Machlup and Penrose (1950), Schiff (1971), Kaufer (1989), Baudenbacher (2012)). According to this literature, "because the Swiss economy was small, the incentive that Swiss industry received from patented exports was arguably greater than the incentive that dominating the domestic Swiss economy via patenting might have supplied" (Moy 1993:486). That is, Switzerland wished "to enrich her own industries by securing technological developments from abroad for nothing" (Kronstein and Till 1948:778-779). In fact, Switzerland did not find it in its interest to enact a national patent system until Germany threatened her with retaliatory tariff action (Schiff (1971), Moy (1993)). The Swiss case shows that it may be advantageous not to have a patent law, assuming that domestic inventive capabilities are sufficient to a "free-ride" by imitating the technologies already developed by foreign enterprises (Kaufer 1989:48).

I complement this view by emphasizing the "political" influence of Swiss radical industries. Radical industries (e.g., chemical and pharmaceutical industries) played an important role in the war against patent protection (Schiff (1971), Baudenbacher (2012)). Indeed, the 1888 patent law excluded chemical, pharmaceutical, and dyeing inventionsfor this reason, Schiff writes that 1888 patent law was "probably the most incomplete and selective patent law ever enacted in modern times" (Schiff 1971:93). While incremental sectors, like the watch-making industry, called for the introduction of a strong national patent system (see Schiff 1971:91), radical sectors opposed this introduction.

Why? One reason derives from different features between radical and incremental innovation. As originated noted by Hall and Soskice (2001), incremental innovation relates with specific investments. Because of specificity, the re-deployment in alternative uses of specific assets is costly. Indeed, specific assets are locked in specific relationships. On the contrary, radical innovation relates with general or multi-purpose investments. This means that the re-deployment of assets is relatively simpler than in incremental innovation and also implies that radical technologies can be more easily imitated and imported from outside than incremental technology. Indeed, while the relocation of incremental innovation would require the relocation of a strict nexus of specific relationships, which in 
turn could involve many assets and agents, the relocation of radical innovation is relatively less reliant on specified, localized, and locked relationships, assets, and agents.

The case of Fuchsin (a chemical product) is paradigmatic of the relative simplicity that exists to import foreign radical innovation.

In 1859, an Alsatian (French) firm had invented an improved method for the production of aniline red, a dyestuff, which it wanted to sell under the name Azalein. Another firm which owned an older French product patent for aniline red that was marketed under the name Fuchsin successfully opposed the sale of Azalein under French law. The Alsatian firm therefore moved its production to Basle where it lawfully produced aniline red under the name Fuchsin at half of the French price (Baudenbacher 2012:476, see also Kronstein and Till (1948:774, fn. 47).

In a similar manner,

[m]ore firms established themselves in Basel at that time and the basis for today's world famous pharmaceutical industry was laid. It has been said that the Basel firms systematically imitated foreign, and in particular, German products. Commentators concluded that the introduction of patent protection was delayed for so many years out of economic opportunism. [...] German industrial circles had called Switzerland a 'pirate state,' the lack of patent protection a 'parasitic system' and accused the Swiss chemical industry of behaving like 'robber barons.' (Baudenbacher 2012:476, italics is added).

Accordingly, by this "institutional arbitrage," several chemical, medical, pharmaceutical firms (i.e., radical firms) moved to Switzerland, enjoying the possibility of freely working and trading resources that in other countries were protected by intellectual property law. In another sense, lobbying activities of radical sectors aimed at freely imitating or importing foreign-patented technologies (at least in the past ${ }^{9}$ ) had stimulated the growth of radical sectors. By this condition on the domain of innovation, via complementarity, Switzerland developed a flexible labour market that fits with radical innovation and supports diffused corporate ownership, namely, a disarmed corporate governance equilibrium that distinguishes the Swiss economy from its neighbouring countries.

\section{Concluding remarks}

Swiss corporate governance, which according to legal origin theory should belong to a civil law system, is characterized by diffused corporate ownership, weak labour protection, and radical innovation and resembles the common law systems more than its

\footnotetext{
${ }^{9}$ More recently, instead, Switzerland became one of the most important supporters of a "rigid" world-wide intellectual property right system. For instance, a report of US department of State of 1996 writes, "Switzerland is a member of all major international intellectual property rights conventions and was an active supporter of a strong IPR text in the GATT Uruguay Round negotiations." (available http://19972001.state.gov/www/issues/economic/trade_reports/europe_canada95/SWITZER.html). One reason could be that today Swiss technology, in particular in radical sectors where Switzerland is a leading economy, can be copied by or move to foreign (especially developing) countries. While Switzerland is not yet able to use the institutional arbitrage for importing or coping foreign technologies, today developing countries may exploit a similar institutional arbitrage to import and/or copy Swiss radical technologies.
} 
neighbouring civil law countries, i.e., Austria, France, Germany, and Italy. This paper claims that the Swiss case is the result of a politics-driven evolution based on institutional complementarity between diffuse corporate ownership and weak employment protection on the one hand and on institutional complementarity between diffuse corporate governance and radical innovations on the other hand.

From the Swiss case, one can learn that institutional complementarities call for an analysis of political context. Each transition (as well as each stasis of an economic system) is always influenced by the past political choices, which may favor or damage the growth of nations by changing the institutions of society.

The Swiss exception results from what did not happen in Switzerland rather than what did. First, Switzerland escaped from the totalitarianism regimes of the 1930s and WWII. This explains the low level of political rights of workers. Second, Switzerland passed through the $19^{\text {th }}$ century without a stringent patent regulation. This permitted the imitation and import of foreign technology, in particular, in radical sectors in which assets are relatively more flexible and less committed. Low protection of workers and radical sectors sustained (and were sustained by) a diffused corporate ownership. Hence, as shown in the case of Switzerland, political choices in the can affect economic outcomes-and this holds true not only for the past and very old political choices as those made between civil vs. common law. 


\section{References}

Amable B. (2015), "Institutional complementarities in the dynamic comparative analysis of capitalism", Journal of Institutional Economics, FirstView Article - September 2015, pp. 1-25.

Anderson M. and T. Hertig (1994), "Institutional investors in Switzerland", in T. Baums, R.M. Buxbaum, and K.J. Hopt (eds.), Institutional investors and corporate governance, Berlin: de Gruyter, pp. 489-530.

Aoki M. (2001), Toward a Comparative Institutional Analysis, Cambridge: MIT Press.

Aoki M. (2010), Corporations in Evolving Diversity: Cognition, Governance and Institutions, Oxford: Oxford University Press.

Baudenbacher C. (2012), "Swiss Economic Law Facing the Challenges of International and European Law," Zeitschrift für Schweizerisches Recht, 131.II.2: 419-673.

Beck T. and R. Levine (2005), "Legal institutions and financial development," in Menard C. and M.M. Shirley (eds.), Handbook of New Institutional Economics, pp. 251-278.

Belloc M. and U. Pagano (2009), "Co-Evolution of Politics and Corporate Governance," International Review of Law and Economics, 29(2): 106-114.

Belloc M. and U. Pagano (2013), "Politics-Business Co-Evolution Path: Workers' Organization and Capitalist Concentration," International Review of Law and Economics, 33(1): 23-36.

Bonoli G. and A. Mach (2001), "The New Swiss Employment Puzzle," Swiss Political Review, 7: 81-94.

Broussolle D. (2009), "Self-Interest, Legal Commitment and Benevolence: The Emergence of a Swiss Labour Market Institution," European Journal of Industrial Relations, 15(3): 277-295.

Carlin W. and C. Mayer (2000), "How do Financial Systems Affect Economic Performance," in X. Vives (ed.), Corporate Governance: Theoretical and Empirical Perspectives, Cambridge: Cambridge University Press, pp. 137-168.

Carlin W. and C. Mayer (2003), "Finance, Investment, and Growth," Journal of Financial Economics, 69(1): 191-226.

Davies, P., Enriques, L., Hertig, G., Hopt, K.J., and Kraakman, R. (2009) Beyond the anatomy. In R. Kraakman et al. (eds.), The Anatomy of Corporate Law: A Comparative and Functional Approach. Oxford: Oxford University Press, pp. 305315.

Duell N., P. Tergeist, U. Bazant and S. Cimper (2010), "Activation Policies in Switzerland," OECD Social Employment and Migration Working Papers. 
European Patent Office (2013), European patent applications per field of technology and per country of residence of the applicant for each individual year from 2004 until 2013. Available at link:

http://documents.epo.org/projects/babylon/eponet.nsf/0/2264C11411AB6B3FC1257 C910042D26F/\$File/European patent applications by country of origin and fiel d_of_technology_2004_2013.xlsx (last access: 06/06/2014).

Faccio M. and L.H.P. Lang (2002), "The Ultimate Ownership of Western European Corporations," Journal of Financial Economics, 65(3): 365-395.

Hall P. A. and D. Soskice (2001), "An Introduction to Varieties of Capitalism," in P. A. Hall and D. Soskice (eds.), Varieties of Capitalism: The Institutional Foundations of Comparative Advantage, Oxford: Oxford University Press, pp. 1-68.

Hofstetter K. (2002), "Corporate Governance in Switzerland," Final Report of the Panel of Experts on Corporate Governance, Swiss Business Federation.

Kaufer E. (1989), The economics of the patent system, Harwood Academic Publishers.

Kronstein H. and I. Till (1948), "A reevaluation of the international patent convention," Journal of Law and Contemporary Problems, 12:765-781

La Porta R., F. Lopez-de-Silanes and A. Shleifer (1999), "Corporate Ownership Around the World," Journal of Finance, 54(2): 471-517.

La Porta R., F. Lopez-de-Silanes and A. Shleifer (2008), "The Economic Consequences of Legal Origins," Journal of Economic Literature, 46(2): 285-335.

La Porta R., F. Lopez-de-Silanes, A. Shleifer and R.W. Vishny (1997), "Legal Determinants of External Finance," Journal of Finance, 52(3): 1131-50.

La Porta R., F. Lopez-de-Silanes, A. Shleifer and R.W. Vishny (1998), "Law and Finance, Journal of Political Economy, 106(6): 1113-55.

Lambelet J.C. (1993) L’Economie Suisse. Paris: Economica.

Lechevalier S. (2014), The great transformation of Japanese capitalism, New York: Routledge.

Le Roy Y. and M.-B. Schönenberger, Introduction générale au droit Suisse, Zurich: Schulthess.

Machlup F. and E. Penrose (1950), "The patent controversy in the nineteenth century," Journal of Economic History, 10(1):1-29.

Mahoney P. (2001), "The common law and economic growth: Hayek might be right, Journal of Legal Studies, 30(2): 503-25.

Mayer C. (2000), “Ownership Matters, Inaugural Lecture, Université Libre de Bruxelles. 
Moy R.C. (1993), "The history of the patent harmonization treaty: Economic self-interest as an influence," John Marshall Law Review, 26:457-495.

North D. C. (1990), Institutions, Institutional Change and Economic Performance, Cambridge: Cambridge University Press.

OECD (2013a), Employment protection annual time series data 1985-2013. Available at link http://www.oecd.org/els/emp/EPL-timeseries.xlsx (last access: 06/06/2014).

OECD (2013b), Employment protection in OECD and selected non-OECD countries in 2013. Available at link http://www.oecd.org/els/emp/EPL-data2013.xlsx (last access: 06/06/2014).

Olson M. (1982), The Rise and the Decline of Nations, New Haven, CT: Yale University Press.

Pagano U. (2012), "The Evolution of the American Corporation and Global Organizational Biodiversity, ” Seattle University Law Review, 35(4): 1271-1298.

Pagano U. and M. Vatiero (2015), "Costly institutions as substitutes: Novelty and limits of the Coasian approach," Journal of Institutional Economics (Coase memorial issue), 11(2): 265-281.

Roe M.J. (2003), Political Determinants of Corporate Governance. Political Context, Corporate Impact, Oxford: Oxford University Press.

Roe M.J. (2006), "Legal Origins, Politics, and Modern Stock," Harvard Law Review, 120(2): 460-527.

Roe M.J. and M. Vatiero (2016), "Corporate governance and its political economy," in J.N. Gordon and W.-G. Ringe (eds.), The Oxford handbook of corporate law and governance, forthcoming.

Schiff E. (1971), Industrialization Without National Patents: The Netherlands, 18691912; Switzerland, 1850-1907, Princeton: Princeton University Press.

Steinberg J. (2011), Why Switzerland?, Cambridge: Cambridge University Press.

Streeck W. (2011), Re-Forming Capitalism. Institutional change in the German political economy, Oxford: Oxford University Press.

Vatiero M. (2016), "On the (political) origin of "corporate governance" species," Journal of Economic Surveys, forthcoming.

Williamson O.E. (1985), The Economic Institutions of Capitalism, New York: The Free Press. 
Appendix

Table 1: Legal origins and corporate ownership

\begin{tabular}{|c|c|c|c|c|c|c|}
\hline \multirow[t]{2}{*}{ Country } & \multirow{2}{*}{$\begin{array}{c}\text { Legal family } \\
\text { (1) }\end{array}$} & \multicolumn{2}{|c|}{$\begin{array}{l}\text { Widely held } 20 \text { largest } \\
\text { firms }\end{array}$} & \multicolumn{2}{|c|}{$\begin{array}{l}\text { Widely held } 10 \\
\text { medium-sized } \\
\text { firms }\end{array}$} & \multirow{2}{*}{$\begin{array}{l}\text { Diffused corporate } \\
\text { ownership (on } \\
\text { average) }\end{array}$} \\
\hline & & $(2 a)$ & $(2 b)$ & $(2 \mathrm{c})$ & $(2 \mathrm{~d})$ & \\
\hline Australia & Common & 0.55 & 0.65 & 0.10 & 0.30 & 0.40 \\
\hline Canada & Common & 0.50 & 0.60 & 0.40 & 0.60 & 0.53 \\
\hline Hong Kong & Common & 0.10 & 0.10 & 0.00 & 0.00 & 0.05 \\
\hline Ireland & Common & 0.45 & 0.65 & 0.50 & 0.63 & 0.56 \\
\hline Israel & Common & 0.05 & 0.05 & 0.10 & 0.10 & 0.08 \\
\hline New Zealand & Common & 0.05 & 0.30 & 0.00 & 0.57 & 0.23 \\
\hline Singapore & Common & 0.05 & 0.15 & 0.10 & 0.40 & 0.18 \\
\hline UK & Common & 0.90 & 1.00 & 0.10 & 0.60 & 0.65 \\
\hline USA & Common & 0.80 & 0.80 & 0.50 & 0.90 & 0.75 \\
\hline Argentina & Civil & 0.00 & 0.00 & 0.00 & 0.00 & 0.00 \\
\hline Austria & Civil & 0.05 & 0.05 & 0.00 & 0.00 & 0.03 \\
\hline Belgium & Civil & 0.00 & 0.05 & 0.10 & 0.20 & 0.09 \\
\hline Denmark & Civil & 0.10 & 0.40 & 0.00 & 0.30 & 0.20 \\
\hline Finland & Civil & 0.15 & 0.35 & 0.00 & 0.20 & 0.18 \\
\hline France & Civil & 0.30 & 0.60 & 0.00 & 0.00 & 0.23 \\
\hline Germany & Civil & 0.35 & 0.50 & 0.10 & 0.10 & 0.26 \\
\hline Greece & Civil & 0.05 & 0.10 & 0.00 & 0.00 & 0.04 \\
\hline Japan & Civil & 0.50 & 0.90 & 0.20 & 0.30 & 0.48 \\
\hline Italy & Civil & 0.15 & 0.20 & 0.00 & 0.00 & 0.09 \\
\hline Mexico & Civil & 0.00 & 0.00 & 0.00 & 0.00 & 0.00 \\
\hline Netherlands & Civil & 0.30 & 0.30 & 0.10 & 0.10 & 0.20 \\
\hline Norway & Civil & 0.05 & 0.25 & 0.10 & 0.20 & 0.15 \\
\hline Portugal & Civil & 0.00 & 0.10 & 0.00 & 0.00 & 0.03 \\
\hline South Korea & Civil & 0.40 & 0.55 & 0.00 & 0.30 & 0.31 \\
\hline Spain & Civil & 0.15 & 0.35 & 0.00 & 0.00 & 0.13 \\
\hline Sweden & Civil & 0.00 & 0.25 & 0.10 & 0.10 & 0.11 \\
\hline Switzerland & Civil & 0.50 & 0.60 & 0.40 & 0.50 & 0.50 \\
\hline \multicolumn{2}{|c|}{ Mean common law systems } & 0.38 & 0.48 & 0.20 & 0.46 & 0.38 \\
\hline \multicolumn{2}{|c|}{ Mean civil law systems } & 0.17 & 0.31 & 0.06 & 0.13 & 0.17 \\
\hline \multicolumn{7}{|c|}{$\begin{array}{l}\text { (1): Countries are distinguished in legal families along with the distinction of La Porta et al. (1998). } \\
\text { (2a), }(2 \mathrm{~b}),(2 \mathrm{c}) \text {, and }(2 \mathrm{~d}) \text { : These indicators are from La Porta et al. (1999). Indicators (2a) and (2b) refer to } \\
\text { the } 20 \text { largest firms ranked by market capitalization of common equity at the end of the year 1995, while } \\
\text { indicators }(2 \mathrm{c}) \text { and }(2 \mathrm{~d}) \text { refer to the smallest } 10 \text { firms in each country with market capitalization of common } \\
\text { equity of at least } \$ 500 \text { million at the end of the year } 1995 \text {. If in the firm there is not one shareholder with } \\
\text { voting rights in the firms exceeding the cut-off value of } 10 \% \text { (indicators in columns } 2 \mathrm{a} \text { and } 2 \mathrm{c}) \text { or } 20 \% \\
\text { (indicators in columns } 2 \mathrm{~b} \text { and } 2 \mathrm{~d}) \text {, the firm is considered widely held. }\end{array}$} \\
\hline
\end{tabular}


Table 2: Legal origins and corporate equilibrium

\begin{tabular}{|l|l|l|l|c|c|c|}
\hline Country & Legal family & \multicolumn{2}{|l|}{$\begin{array}{l}\text { Diffused corporate } \\
\text { ownership (on } \\
\text { average) }\end{array}$} & \multicolumn{2}{l|}{ Employment protection } & \multicolumn{2}{l|}{$\begin{array}{l}\text { Disarmed corporate } \\
\text { governance equilibrium }\end{array}$} \\
\hline & $(1)$ & $(2)$ & $(3 \mathrm{a})$ & $(3 \mathrm{~b})$ & $(3 \mathrm{c})$ & $(4)$ \\
\hline & & & & & & \\
\hline Canada & Common & $\mathbf{0 . 5 3}$ & 0.75 & 0.92 & $\mathbf{0 . 1 4}$ & $\mathbf{0 . 5 3}+(\mathbf{1 - 0 . 1 4})=\mathbf{1 . 3 9}$ \\
\hline UK & Common & $\mathbf{0 . 6 5}$ & 0.60 & 1.03 & $\mathbf{0 . 1 4}$ & $\mathbf{1 . 5 1}$ \\
\hline USA & Common & $\mathbf{0 . 7 5}$ & 0.21 & 0.26 & $\mathbf{0 . 0 4}$ & $\mathbf{1 . 7 1}$ \\
\hline Austria & Civil & $\mathbf{0 . 0 3}$ & 2.21 & 2.75 & $\mathbf{0 . 4 1}$ & $\mathbf{0 . 6 2}$ \\
\hline France & Civil & $\mathbf{0 . 2 3}$ & 2.98 & 2.34 & $\mathbf{0 . 4 4}$ & $\mathbf{0 . 7 9}$ \\
\hline Germany & Civil & $\mathbf{0 . 2 6}$ & 3.09 & 2.68 & $\mathbf{0 . 4 8}$ & $\mathbf{0 . 7 8}$ \\
\hline Italy & Civil & $\mathbf{0 . 0 9}$ & 3.57 & 2.76 & $\mathbf{0 . 5 2}$ & $\mathbf{0 . 5 7}$ \\
\hline Switzerland & Civil & $\mathbf{0 . 5 0}$ & 1.14 & 1.60 & $\mathbf{0 . 2 3}$ & $\mathbf{1 . 2 7}$ \\
\hline & & & & & \\
\hline
\end{tabular}

(1): Countries are distinguished in legal families along with the distinction of La Porta et al. (1998).

(2): Index in the column (3) of the Table 1.

(3a): This indicator is from OECD (2013a) and refers to the year 1995- the year of data on corporate ownership. It is expressed on a scale from 0 (lowest employment protection) to 6 (highest employment protection).

(3b) This indicator is from OECD (2013b) and refers to the year 1995- the year of data on corporate ownership. It is expressed on a scale from 0 (lowest employment protection) to 6 (highest employment protection).

(3c) This index is the average of indicators of OECD in the preceding columns (3a, 3b), normalized to 1.

(4) This index is the result of the following sum: the rate of widely held firms (column 2) + the complement to 1 of the indicator of employment protection (column 3c). A higher index stands for a corporate equilibrium with lower employment protection and lower corporate concentration, namely, a more "disarmed" corporate equilibrium. 
Table 3: Legal origins, corporate governance, and innovation

\begin{tabular}{|l|l|c|c|}
\hline Country & Legal family & $\begin{array}{l}\text { Disarmed corporate } \\
\text { governance equilibrium }\end{array}$ & $\begin{array}{l}\text { Radicalness of } \\
\text { innovation }\end{array}$ \\
\hline & \multicolumn{1}{|c|}{$(1)$} & $(2)$ & $(3)$ \\
\hline & & & $\mathbf{1 . 3 6}$ \\
\hline Canada & Common & $\mathbf{1 . 3 9}$ & $\mathbf{1 . 2 4}$ \\
\hline UK & Common & $\mathbf{1 . 5 1}$ & $\mathbf{1 . 6 3}$ \\
\hline USA & Common & $\mathbf{1 . 7 1}$ & $\mathbf{0 . 5 4}$ \\
\hline Austria & Civil & $\mathbf{0 . 6 2}$ & $\mathbf{0 . 8 1}$ \\
\hline France & Civil & $\mathbf{0 . 7 9}$ & $\mathbf{0 . 6 1}$ \\
\hline Germany & Civil & $\mathbf{0 . 7 8}$ & $\mathbf{0 . 6 5}$ \\
\hline Italy & Civil & $\mathbf{0 . 5 7}$ & $\mathbf{1 . 2 1}$ \\
\hline Switzerland & Civil & $\mathbf{1 . 2 7}$ & \\
\hline & \multicolumn{2}{|l}{}
\end{tabular}

(1): Countries are distinguished in legal families along with the distinction of La Porta et al. (1998).

(2): Index in the column (4) of the Table 2.

(3) Using data on the number of granted patents by European Patent Offices, I created an index of radicalness of innovation for selected nations (US, UK, Canada, Switzerland, Austria, France, Germany, and Italy). This index denotes the specialism of a country in selected radical sectors (biotechnology, pharmaceuticals, medical technology and computer technology) relative to selected incremental sectors (transport, civil engineering and mechanical elements) by using data from the years 2004-2013 on the number of granted patents by European Patent Offices. The index is calculated as follows:

$$
i_{\text {country }}=\frac{\text { PatRad }_{i}}{\text { PatRaD }_{n}} / \frac{\text { Pat }_{i}}{\text { Pat }_{n}}
$$

where $i$ indicates the index for a certain country, $n$ all countries of the sample, and PatRad and Pat stand for, respectively, the number of patents in selected radical sectors, and the number of patents in all selected sectors (i.e.: radical + incremental). 


\section{IdEP Economic Papers}

The series IdEP Economic Papers, ideally continues the work of the "Quaderni della Facoltà" the publication of which began in 1998 and ended in 2013.

For a complete list of the Quaderni see: http://econpapers.repec.org/paper/lugwpaper/

IdEP Economic Papers also gathers the legacy of the CEPRA Working Papers, published from 2012 to 2013.

The full list at: http://econpapers.repec.org/paper/lugwcepra/

\section{4:}

No. 01

F. Mazzonna, F. Peracchi, Unhealthy retirement? Evidence of occupation heterogeneity

No. 02

L. Di Giorgio, M. Filippini, G. Masiero, The relationship between costs and quality in nonprofit nursing homes

No. 03

F.C. Billari, V. Galasso, Fertility decisions and pension reforms : evidence from natural experiments in Italy

No. 04

M. Jametti, M. Joanis, Elections and de facto expenditure decentralization in Canada

No. 05

M. Jametti, Weathering the global financial crisis : is direct democracy of any help?

No. 06

U. Pagano, M. Vatiero, Costly institutions as substitutes : novelty and limits of the Coasian approach

No. 07

R. Parchet, Are local tax rates strategic complements or strategic substitutes?

No. 08

R. Ippoliti, M. Vatiero, An analysis of how 2002 judicial reorganization has impacted on the performance of the First Instance Courts (Preture) in Ticino

No. 09

F. Mazzonna, P. Salari, Short term effects of public smoking bans on health 
2015:

No. 01

S. Galletta, Direct democracy, partial decentralization and voter information : evidence from Swiss municipalities

No. 02

I. Sarman, Second homeowners' intention to move : an integrated ordered logit model with latent variable

No. 03

M.J. Roe, M. Vatiero, Corporate governance and its political economy

No. 04

M. Filippini, M. Koller, G. Masiero, Competitive tendering versus performance-based negotiation in Swiss public transport

No. 05

O. Giuntella, F. Mazzonna, If you don't snooze you lose health and gain weight : evidence from a regression discontinuity design

No. 06

M. Filippini, B. Hirl, G. Masiero, Rational habits in residential electricity demand

2016:

No. 01

S. Galletta, Law enforcement, municipal budgets and spillover effects : evidence from a quasiexperiment in Italy

No. 02

S. Galletta, A. Redonda, Corporate flat tax reforms and businesses' location choices. Evidence from Switzerland

No. 03

M. Filippini, W. Greene, G. Masiero, Persistent and transient productive inefficiency in a regulated industry : electricity distribution in New Zealand

No. 04

M. Vatiero, On the (political) origin of "corporate governance" species

No. 05

E. Gentili, G. Masiero, F. Mazzonna, The role of culture in long-term care

No. 06

M. Vatiero, Learning from the Swiss corporate governance exception 